\section{Post herpetic neuralgia}

\section{The herpes virus}

In Romeo and Juliet (I.iv), Shakespeare gives a possible description of herpes simplex:

"O'er ladies' lips, who straight on kisses dream;

Which oft the angry Mab with blisters plagues."

William Heberden distinguished chickenpox from smallpox in 1767 in a report to the Royal College of Physicians. In 1875 Steiner transmitted varicella to children by inoculating fluid from the vesicles of chickenpox patients, thus establishing its infectious nature.

James Von Bokay in $1892^{1}$ first questioned:

"whether or not the unknown infectious material of chickenpox could under certain circumstances manifest itself instead as a zoster eruption."

In 1904 Ernest Tyzzer studied epidemics in a Philippines prison; he concluded that smallpox and chickenpox were different illnesses and proved that they could be separated by microscopy of skin biopsies (where he saw large multinucleated cells in varicella but not in smallpox). In 1925 Kundratitz demonstrated that vesicular fluid from zoster patients could produce varicella when inoculated into susceptible children. In 1948 the virus was revealed by electron microscopy. The isolation of the virus from zoster and varicella patients was the work of Weller and Stoddard ${ }^{2}$ in 1952 and that the same virus was common to both diseases was recognised by Weller et al in 1958. HopeSimpson deduced that herpes zoster was caused by reactivation of dormant varicella-zoster virus.

\section{Post-herpetic neuralgia}

Clinically, post-herpetic neuralgia (PHN) behaves as a "central" or deafferentation pain, resistant to peripheral destructive procedures.

Richard Bright suspected a link between herpes zoster and the peripheral nerve apparatus in $1831 .^{3}$ The first postmortem examination-which identified the damage in the dorsal root ganglion-was performed by von Bärensprung in $1861 .^{4}$

Medical knowledge remained rudimentary until Henry Head with A W Campbell (pathologist to Rainhill County Asylum) studied herpes zoster. ${ }^{56}$ Head lived in the hospital for two years recording 450 cases and 21 autopsy studies. Foerster commended the accuracy of Head's observations when compared to the method of section of nerve roots. Crucially, from this investigation the understanding of segmental dermatomes arose. Head and Campbell mapped the dermatomes and showed that each corresponded to a single dorsal root ganglion (DRG). They characterised the onset and progression of the disease from ganglionitis to post-herpetic neuralgia.

Despite these contributions the pathophysiology remained incomplete. In 1964, Zacks, Langfitt, and Elliot ${ }^{7}$ reported on biopsied peripheral nerves in four zoster patients, two with post-herpetic neuralgia. Wallerian degeneration was present, but neural fibrosis did not correlate with PHN. A central pain mechanism was suspected because few fibres remained. Smith $^{8}$ excised DRGs in 16 patients with intractable intercostal PHN. Some were cystic and even at one year some were infiltrated with chronic inflammatory cells. Watson and colleagues carried out extensive pathological studies of nerve root and dorsal ganglion and cord. ${ }^{9}$ In four post-herpetic neuralgia cases, shrinkage of the ipsilateral dorsal horn was combined with loss of DRG neurones and peripheral large myelinated axons. However, one of the cases without PHN had an ipsilateral myelopathy with loss of myelinated axons indistinguishable from chronic post-herpetic neuralgia. ${ }^{10}$ Thus, there was no specific pathology to correlate with the presence or absence of neuralgia.

Noordenbos, in 1959, using intercostal nerve biopsies showed a reduction of large diameter myelinated fibres and proposed that the predominant loss of large myelinated afferents leads to a loss of their central inhibitory effects on pain produced by small diameter C-fibre nociceptive afferents. ${ }^{11}$ Noordenbos's hypothesis of the unrestrained effects of C-fibre input into the cord became influential in Melzack and Wall's gate control hypothesis. ${ }^{12}$

Patients with post-herpetic neuralgia are classified into: (1) an irritable nociceptor group with minimal deafferentation and touch evoked allodynia owing to peripheral nociceptor input; (2) a deafferentation group with marked sensory loss and no allodynia; and (3) a deafferentation group with sensory loss and allodynia owing to central reorganisation. Post-herpetic neuralgia correlates with allodynia and altered sensory thresholds to several modalities. Somatotopic remodelling or central sensory reorganisation ${ }^{13}$ are the words often applied to the creation of pain: though words of conjecture they remain.

J M S Pearce
304 Beverley Road, Anlaby, East Yorkshire HU10 7BG, UK;
jmsp@freenet.co.uk

\section{References}

1 Von Bokay J. Uber den atiologischen Zusammenhang der Varizellan mit gewissen Fallen von Herpes Zoster Wien Zlin Wochenschr 1909;22:1323-6. [Bokay's first paper Hungarian paper was published in 1892, translated by Jako\& Jako, 1986, cited by Weller TH. In: Varicella-zoster virus, Ed Arvin AM, Gershon AA, Cambridge Univ Press, 2000 pp 9-25].

2 Weller TH, Stoddard MB. Intranuclear inclusion bodies in cultures of human tissue inoculated with varicella vesicle fluid. J Immunol 1952;68:311-9.

3 Bright R. Reports of Medical Cases, Selected With a View of Illustrating the Symptoms and Cure of Diseases by a Reference to Morbid Anatomy. 2 volumes, London, Longmans, 1827-1831. Facsimile of volume 1. London: Gower Publishers \& Royal Society of Medicine, 1985, [The second part published in 1831 was devoted to the nervous system, illustrations appearing in a separate volume].

4 Von Barensprung FGF. Betrage zur Kenntnis des Zoster. Berlin: Ann d Char Krankenheit, 1862;10:96-104.

5 Head H, Campbell AW. The pathology of herpes zoster and its bearing on sensory localization. Brain 1900;23:353-529.

6 Henson RA. Henry Head: his influence on the development of ideas on sensation. Br Med Bull 1977;33:91-6.

7 Zacks SI, Langfitt TW, Elliott FA. Herpetic neuritis: a light and electron microscopic study. Neurology 1964;14:744-50.

8 Smith FP. Pathological studies of spinal nerve ganglia in relation to intractable intercostal pain. Surgical Neurology 1978;10:50-3.

9 Watson CPN, Deck JH. The neuropathology of herpes zoster with particular reference to postherpetic neuralgia and its pathogenesis. In: Watson CPN, eds. Herpes zoster and postherpetic neuralgia. Amsterdam: Elsevier, 1993:139-58.

10 Watson CPN, Deck JH, Morshead C, et al. Postherpetic neuralgia: further post-mortem studies of cases with and without pain. Pain 1991;44:105-17.

11 Noordenbos W. Pain. Amsterdam: Elsevier, 1959:68-80.

12 Melzack R, Wall PD. Pain mechanisms: a new theory. Science 1965;150:971-78.

13 Leading article. Postherpetic neuralgia. Lancet 1990;336:37-8. 